\title{
Automatically Unfair and Operational Requirement Dismissals: Making Sense of the 2014 Amendments
}

\author{
K Newaj* and S van Eck ${ }^{\star \star}$
}

\section{P.E.R}

Pioneer in peer-reviewed, open access, online law publications.

Authors

Kamalesh Newaj and Stefan van Eck

Affiliation

University of Pretoria,

South Africa

\section{Email}

kamalesh.newaj@up.ac.za

stefan.vaneck@up.ac.za

Date published

12 December 2016

Editor Prof W Erlank

How to cite this article

Neway $\mathrm{K}$ and van Eck S

"Automatically Unfair and

Operational Requirement

Dismissals: Making Sense of the

2014 Amendments" PER / PELJ

2016(19) - DOI

http://dx.doi.org/10.17159/1727-

3781/2016/v19n0a1203

Copyright

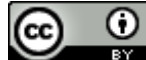

DOI

http://dx.doi.org/10.17159/17273781/2016/v19n0a1203

\begin{abstract}
This article explores the concept of the automatic unfair dismissal that is regulated in $\mathrm{s} 187(1)$ (c) of the Labour Relations Act 66 of 1995 (LRA), where the reason for the dismissal is to "compel the employee to accept a demand in respect of any matter of mutual interest". This provision raised important questions of law, as it brought to the fore the conflict that existed between this provision and sections 188(1)(a)(ii) and 189 of the LRA, which permits dismissals for operational requirements. This dichotomy was dealt with by the court in Fry's Metals (Pty) Ltd $v$ National Union of Metalworkers of SA 2003 ILJ 133 (LAC), but the decision was controversial and faced criticism. The decision of the court was consequently rendered incorrect, resulting in the amendment to $s$ 187(1)(c), which now reads that a dismissal is automatically unfair if the reason for the dismissal is a refusal by employees to accept a demand in respect of any matter of mutual interest between them and their employer. However, it is doubtful whether the amended provision provides a solution to the contradiction that exists. Resultantly, this article seeks to critique the amendment and to make recommendations regarding the regulation of this part of labour law.
\end{abstract}

\section{Keywords}

Amendments to the Labour Relations Act (LRA); automatic unfair dismissal; dismissal on grounds of operational requirements; disputes of interest; disputes of right. 


\section{Introduction}

The section of labour law where the definition of "automatically unfair dismissal", ${ }^{1}$ the employer's right to terminate contracts of employment on the ground of operational requirements ${ }^{2}$ and the institution of collective bargaining overlap, creates controversial legal ground. ${ }^{3}$

After South Africa's first democratic elections, the Cheadle Task Team included the definition of an "automatic unfair dismissal" in the Labour Relations Act 66 of 1995 ("the LRA of 1995"). This section stated that it constitutes an "automatic unfair dismissal" "if the reason for dismissal is to compel the employee to accept a demand in respect of any matter of mutual interest". ${ }^{4}$

A barrage of criticism was levelled against the way in which this definition of the LRA of 1995 was interpreted by the Labour Appeal Court ${ }^{5}$ ("the LAC") and the Supreme Court of Appeal ("the SCA") in the Fry's Metals cases. ${ }^{7}$ On 1 January 2015 the Labour Relations Amendment Act 6 of

\footnotetext{
* Kamalesh Newaj. BCom(Law); LLB; HDip (Labour Law); LLM (UP). Lecturer, Department of Mercantile Law, University of Pretoria. Email: kamalesh.newaj@up.ac.za.

** Stefan van Eck. BLC, LLB, LLD (UP). Professor, Department of Mercantile Law, Faculty of Law, University of Pretoria. Director of the Centre of Insolvency, Labour and Company Law (CILC). Email: stefan.vaneck@up.ac.za.

1 Section 187(1)(c) of the Labour Relations Act 66 of 1995 (hereafter the LRA of 1995).

2 Section 188(1)(a)(i) of the LRA of 1995.

3 The seeds of uncertainty were already sown during the era of the Industrial Court ("the IC"). It grappled with the boundaries of the concepts of "lock-out dismissals" and "collective bargaining". See Commercial Catering and Allied Workers Union v Game Discount World Ltd 1990 ILJ 162 (IC).

4 Section 187(1)(c) of the LRA of 1995.

5 Fry's Metals (Pty) Ltd v National Union of Metalworkers of SA 2003 ILJ 133 (LAC) (hereafter Fry's Metals, LAC).

$6 \quad$ National Union of Metalworkers of South Africa v Fry's Metals (Pty) Ltd 2005 ILJ 689 (SCA) (hereafter Fry's Metals, SCA). Also see the cases in which the Fry's Metals cases are referred to, including Chemical Workers Industrial Union v Algorax (Pty) Ltd 2003 ILJ 1917 (LAC) (hereafter the Algorax case); General Food Industries Ltd v Food and Allied Workers Union 2004 ILJ 1260 (LAC); and Mazista Tiles (Pty) Ltd v National Union of Mineworkers 2004 ILJ 2156 (LAC).

7 So, for example, Thompson 2006 ILJ 730 argues for the removal of the statutory "prohibition against tactical and temporary dismissals from the category of automatically unfair dismissals" as it "simply does not belong there and spawns anomalies". In the alternative, he argues that policy-makers could consider amending the LRA of 1995 to prohibit permanent economic terminations expressly, but to make allowance for employers to employ replacement labour during offensive lock-outs. Grogan 2003 ELJ 11 continues that it "seems somewhat strange that the legislature should have categorised conditional dismissals in the context of collective bargaining as automatically unfair". Also see Qotoyi and Van Der Walt 2009 Obiter 79.
} 
2014 ("the LRAA of 2014") came into effect and, amongst other things, it aimed to clarify the situation surrounding automatic unfair dismissal, operational requirement dismissals and collective bargaining. ${ }^{8}$ The authors argue that it is doubtful that the amendment of section 187(1)(c) of the LRA of 1995 provides the appropriate solution to the on-going contradictions referred to below. This contribution seeks to unravel this minefield of uncertainty, to critique the recent amendment and to make recommendations regarding the regulation of this aspect of labour law.

\section{Salient aspects of the LRA}

The LRA of 1995 does not contain an enforceable duty to engage in collective bargaining. ${ }^{9}$ Despite this, section 1 of the LRA of 1995 in no uncertain terms promotes collective bargaining as the means by which "wages, terms and conditions of employment and other matters of mutual interest" should be determined. ${ }^{10}$ Collective bargaining is also bolstered in so far as trade unions are accorded organisational rights ${ }^{11}$ and there is an unambiguous recognition of the right to strike. ${ }^{12}$

During the process of collective bargaining the dismissal of workers is prohibited when it aims to force workers to agree to changes of conditions of service. ${ }^{13}$ Simply put, these disputes should be resolved though collective bargaining and power-play and not through threats of dismissal. When workers engage in strike action, employers have the recourse to lock-out in response to a strike, and to employ replacement labour. ${ }^{14}$ However, they are not at liberty to take the initiative in forcing the issue of amending conditions of service by dismissing workers who do not accept the demand, ${ }^{15}$ or by means of an offensive or attacking lock-out and the employment of replacement labour. ${ }^{16}$ This is the framework established for the resolution of collective bargaining disputes.

8 The Memorandum of Objects: Labour Relations Amendment Bill, 201217 alludes to the fact that the LRA of 1995 "is amended to remove an anomaly arising from the interpretation of $S 187(1)(c)$ in National Union of Metalworkers of SA v Fry's Metals (Pty) Ltd (2005) 26 ILJ 689 (SCA)".

Vettori 2005 De Jure 382.

Section 1 of the LRA of 1995.

Sections 11-16 of the LRA of 1995.

Section 64(1) of the LRA of 1995.

Section 187(1)(c) of the LRA of 1995.

4 See SACTWU v Stuttafords Department Stores Ltd 1999 ILJ 2692 (LC); Stuttafords Department Stores Ltd v SACTWU 20011 BLLR 46 (LAC).

15 Section $187(1)(c)$ of the LRA of 1995.

16 Section 76(1)(b) of the LRA of 1995. Ntimane $v$ Agrinet 19993 BLLR 248 (LC). 
Despite this neat structure, there is a dichotomy in the LRA of 1995 in so far as the employer retains the right to terminate workers' employment on the grounds of economic reasons as long as this is in line with the canons of fairness. The LRA of 1995 recognises three reasons, subject to appropriate procedures being followed, which could potentially constitute a fair dismissal. ${ }^{17}$ These are the employee's conduct, the employee's capacity, and the employer's operational requirements. ${ }^{18}$ The notion "operational requirements" is defined in broad terms. It covers requirements based on "the economic, technological, structural or similar needs of an employer". ${ }^{19}$ While it is impossible to define all the circumstances that might legitimately form the basis of a dismissal for this reason, the Code on Dismissal Based on Operational Requirements states that economic reasons are those that relate to the "financial management of the enterprise", technological reasons to "the introduction of new technology which affects work relationships", and structural reasons those that "relate to the redundancy of posts consequent to a restructuring of the employer's enterprise". ${ }^{20}$

Such terminations are often associated with the economic subsistence of the employer. For some time before the Fry's Metals cases, the courts showed a willingness to adopt a more interventionist approach and to scrutinise the reasons for the decision to dismiss. In Chemical Workers Industrial Union v Algorax ${ }^{21}$ ("Algorax") it was the approach of the LAC that retrenchment comes as a measure of last resort rather than merely relying on the "say-so" of the employer. Differently stated, the employer should usually have its proverbial back against the wall to prove substantive fairness before terminating the employment of a portion of the workforce. Nonetheless, this is not always the case. Even though it may appear a drastic norm, it is also an accepted South African legal principle that employers are at liberty to reduce the number of workers to increase profits. ${ }^{22}$

17 Section 187(1)(c) of the LRA of 1995.

18 Section 188(1) of the LRA of 1995. See further Schedule 8 (Code of Good Practice: Dismissal) item 2(2), which directs that the LRA of 1995 "recognises three grounds on which a termination might be legitimate. These are: the conduct of the employee, the capacity of the employee, and the operational requirements of the employer's business".

19 Section 213 of the LRA of 1995.

20 Item 1 of the Code on Dismissal Based on Operational Requirements (Gen N 1517 in GG 20254 of 16 July 1999). Also see Du Toit et al Labour Relations Law 473.

212003 ILJ 1917 (LAC). Also see Van Niekerk and Smit Law@work 315 and the discussion of the Algorax case by Du Toit 2005 ILJ 598-602.

22 See Mazista Tiles (Pty) Ltd v National Union of Mineworkers 2004 ILJ 2156 (LAC). 
In addition, an employer must in terms of section 189 of the LRA of 1995, when contemplating the dismissal of workers on operational grounds, "engage in a meaningful joint consensus-seeking process" with workers' representatives to consider "alternatives that the employer considered", which could potentially limit or avoid the dismissals. ${ }^{23}$ This could include the working of short time, the lowering of salaries and other amendments to conditions of service. Failing agreement, the employer retains the right to terminate the contracts of employment on the grounds of operational requirements. Subsequent to this, if contested, it is left to arbitrators or judges to determine whether or not such dismissals are substantively and procedurally fair. The problem is that when an employer contemplates adapting its workers' conditions of service during operational requirements consultations, the parties could potentially enter the realm of collective bargaining, and employers are not supposed to dismiss workers to force them to accept a demand.

Strikes and lock-outs form an integral part of the process of collective bargaining. During industrial action employers and workers are engaged in concerted actions which have as their ideal the attainment of a collective agreement which spells out the changed conditions of employment. The definitions of "strike" and "lock-out" in terms of the LRA of 1995 limit these types of actions to so-called disputes of "mutual interest". ${ }^{24}$ This ensures that strikes and lock-out do not coincide with claims, such as political disputes, about which the employer has limited ability to influence the outcome. ${ }^{25}$

The term "mutual interest" is not defined in the LRA of 1995. However, the courts have given the term a wide meaning. ${ }^{26}$ In De Beers Consolidated Mines $v$ CCMA $^{27}$ it was held that the term must be interpreted literally to mean "any issue concerning employment". 28 The broadness of the concept is aptly captured by Thompson as follows:

In some labour law systems, it is accurate to speak of business matters over which the unions have no say. That is not the case in South Africa. A union can push for a collective agreement on any matter of mutual interest between employer and employee, and it can engage in a protected strike on

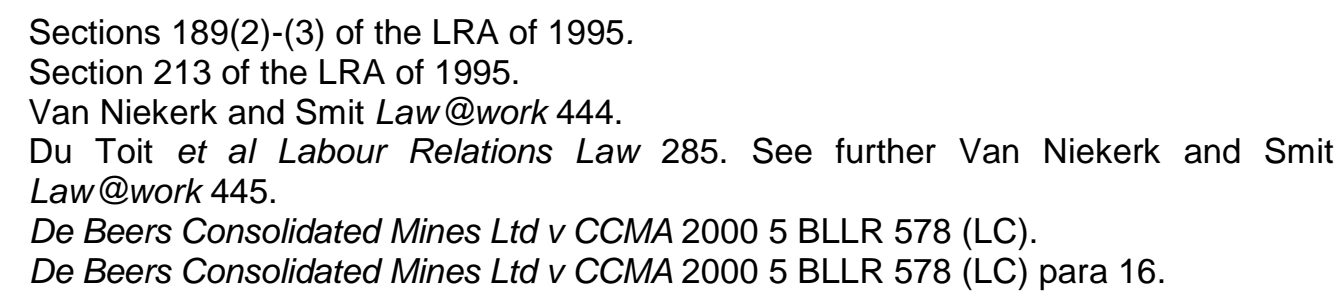


anything impacting on the employment relationship. No employer decision bearing on employment is immune from industrial or legal challenge. ${ }^{29}$

Even though the LRA of 1995 does not make such a distinction, labour law scholars often differentiate between disputes of interest and disputes of right. As pointed out by Van Niekerk and Smit, the notion dispute of mutual interest is wide enough to include both of these categories of disputes. ${ }^{30}$ Interest disputes involve the creation of new rights or the adaptation of existing rights. ${ }^{31}$ This differs from a dispute of right, which concerns a legal claim under an employment contract, a collective agreement, a statute or even the common law. In such instances the dispute concerns a breach of a pre-existing right. ${ }^{32}$

The importance of this classification lies in the mechanisms available to address these varying disputes. Strikes and lock-outs are generally not an option in relation to the resolution of disputes of right, as such matters must be finalised through arbitration or adjudication. The LRA of 1995 provides that no person may strike or lock-out "if the issue in dispute is one that a party has the right to refer to arbitration or the Labour Court" for resolution in terms of the LRA of $1995 .{ }^{33}$ Conversely so, a dispute of interest must be resolved by means of the bargaining process itself. ${ }^{34}$

Against this backdrop, a variation to terms and conditions of employment would mostly locate itself within the realm of interest disputes and hence the mechanism of collective bargaining would be the appropriate

29 Thompson 1999 ILJ 758-759.

30 Van Niekerk and Smit Law@work 445 allude to the fact that a "dispute about a matter of mutual interest should not be equated with an interest dispute - these are very different concepts. Interest disputes, like rights disputes, when they arise in the context of an employment relationship, are subsets of the broader category of disputes about matters of mutual interest. In other words, disputes about 'matters of mutual interest' include disputes of right as well as disputes of interest".

31 This was confirmed in National Union of Metalworkers of SA v Fry's Metals (Pty) Ltd 2001 ILJ 701 (LC) para 25 (hereafter Fry's Metals, LC). Also see Cohen 2004 ILJ 1884-1885. The author states that "[p]roposed changes to terms and conditions of employment can be classified as an interest dispute, being a dispute in which the claimant party seeks a benefit or advantage to which he has no legal entitlement. In terms of the LRA 1995, interest disputes are intended to be resolved through the collective bargaining process".

32 Thompson 1999 ILJ 757 confirms that the "starting-point is the reminder that our system works explicitly with the distinction between disputes of right and disputes of interest". Notwithstanding this, the distinction is not always absolute. Van Niekerk and Smit Law@work 446 mentions that this "is not a clean distinction - there are at least two categories of dispute where parties have a choice of either arbitration or adjudication on the one hand or industrial action on the other. These are disputes about organisational rights and disputes about whether there is a fair reason for a dismissal on account of the employer's operational requirements".

33 Section 65(1)(c) of the LRA of 1995.

34 Thompson 1999 ILJ 757-758. 
remedy. ${ }^{35}$ On the other hand, the dismissal of workers on operational grounds would be classified a dispute of right, and arbitration or adjudication would be the appropriate process to resolve such disputes.

As a general rule, the LRA of 1995 prohibits the dismissal of workers engaged in protected strike action. The LRA of 1995 confirms this by providing that "an employer may not dismiss an employee for participating in a strike" or, for that matter, "for any conduct ... in the furtherance of a protected strike". ${ }^{36}$ This section is bolstered by the inclusion of the prohibition of automatically unfair dismissals, which is discussed below. However, there is an exception to the rule. Employers are permitted in the course of a strike to dismiss employees based on operational reasons.

Section 67(5) provides that subsection (4) does not limit:

$\ldots$ an employer from fairly dismissing an employee in accordance with Chapter VIII ... during the strike ... for a reason based on the employer's operational requirements.

These provisions clash. We say this because on the one hand an employer may terminate workers' employment for operational reasons during strikes in terms of section 67(5) of the LRA of 1995. However, on the other hand the employer may not terminate its workers' employment to compel the employees to accept a demand in respect of any matter of mutual interest in terms of the automatic unfair dismissal provisions in terms of section $187(1)$ of the LRA of $1995 .{ }^{37}$

\section{Understanding the dichotomy}

The starting point of our argument is that there may be legitimate circumstances that require the terms and conditions of employment to be changed in order to maintain the viability of the employer's business. As fittingly stated by Thompson:

In a market economy driven by competition, change is a fact of life. Businesses must adapt constantly to stay in the game, and this entails ongoing changes to terms and conditions of employment. Everyone has an

35 Collective agreements which are the product of collective bargaining are defined in $\mathrm{s}$ 213 of the LRA of 1995 as written agreements concerning terms and conditions of employment or any other matter of mutual interest. The LRA of 1995 further provides for the right to strike, strike being defined in $s 213$ as the partial or complete concerted refusal to work, or the retardation or obstruction of work, by persons who are or have been employed by the same employer or by different employers, for the purpose of remedying a grievance or resolving a dispute in respect of any matter of mutual interest between employer and employee.

36 Section $67(4)$ of the LRA of 1995.

37 This principle was confirmed by the LAC in SA Chemical Workers Union v Afrox Ltd 1999 ILJ 1718 (LAC) para 29. 
interest in the continuing progress of individual firms and the economy as a whole. ${ }^{38}$

However, when it comes to making these changes, the employer's legal options are limited. ${ }^{39}$ Due to the fact that the amendment of working conditions of service falls into the basket of interest disputes, consensus is generally required before changes may be made, which is not always possible to attain through power play. The only tool available to the employer is that of a retaliatory lock-out to force workers to accept the employer's demand to amend conditions of service. ${ }^{40}$ An employer may not take into employment any person to perform the work of any employee who is locked out, unless the lock-out is in response to a strike. ${ }^{41}$ However, as pointed out by Mischke:

[even though] the employer may contemplate exercising its economic power in the form of a lock out - [it is] hardly the most appropriate course of action for an employer already perhaps facing considerable economic pressure. The resulting loss of production and the fall-out of a lock-out may very well constitute the last straw for a struggling employer. ${ }^{42}$

Furthermore, section 187(1)(c) of the LRA of 1995, previously determined

[a] dismissal is automatically unfair if the reason for the dismissal is to compel the employee to accept a demand in respect of any matter of mutual interest between the employer and employee.

Notwithstanding the mechanism of collective bargaining as espoused in the LRA of 1995, as well as the protection provided by section 187(1)(c) of the LRA, there have been instances in which employers have resorted to the dismissal of employees after a rejection of proposed changes to terms and conditions of employment. ${ }^{43}$ In such instances the employer's assertion has been that the proposed changes were necessary for operational reasons. ${ }^{44}$ However, what has caused much controversy is the question of whether these dismissals for operational requirements amount to unfair dismissals.

38 Thompson 2006 ILJ 705.

39 Mischke 2003 CLL 31.

40 A "lock-out" is loosely defined in s 213 of the LRA of 1995 as the exclusion by an employer of employees from the workplace for the purpose of compelling the employees to accept a demand in respect of any matter of mutual interest between employer and employee, whether or not the employer breaches those employees' contracts of employment in the course of, or for the purpose of, that exclusion.

41 Section 76(1)(b) of the LRA of 1995.

42 Mischke 2003 CLL 32.

43 Relying on $S$ 188(1)(a)(ii) of the LRA of 1995.

44 Such as Fry's Metals, LAC; Fry's Metals, SCA; Mazista Tiles (Pty) Ltd v National Union of Mineworkers 2004 ILJ 2156 (LAC) and the Algorax case. 
What follows is an examination of the decisions by the LAC and SCA in the Fry's Metals cases and the amendment that has been made to section 187(1)(c) of the LRA of 1995.

This is an important matter. As stated by Thompson, these are not "abstract concepts" but are very significant issues for both workers and employers. It is important to understand "just how does the law conceive of the contest" when the interests of parties conflict, and "on what basis will matters be decided should the parties go to court". ${ }^{45}$

We contend that this question remains relevant ten years later. As discussed below, the section has been tweaked by the LRAA of 2014 . However, it remains to be seen whether the legal issues have been resolved.

\section{Prelude to Fry's Metals: the lock-out dismissal}

The key to understanding the Fry's Metals decisions and the recent amendment to the LRA of 1995 lies in the wording of the definition of "lock-out" in terms of the former Labour Relations Act 28 of 1956 ("the LRA of 1956") and the interpretation of fair and unfair bargaining tactics by the IC. A "lock-out" was defined as:

any one or more of the following acts or omissions by a person who is or has been an employer - ......

(c) the breach or termination by him of the contracts of employment of any body ... in his employ; or

(d) the refusal ... by him to re-employ any body ... who have been in his employ,

if the purpose of that ... breach, termination, refusal or failure is to induce or compel any persons, who are or have been in his employ ... -

(i) to agree or comply with any demands or proposals concerning terms or conditions of employment. ${ }^{46}$

The definition had a wide meaning and included the "termination" of employment as long as it was associated with the purpose of persuading workers to accept a demand. If this criterion was met, the action fell within the realm of lock-outs. This, in turn, formed part of the "acceptable" process of the amendment of conditions of service, which falls within the arenas of power-play and disputes of interest.

The IC had wide powers to impose a duty to engage in collective bargaining within the realm of its role as watchdog under the LRA of 1956,

45 Thompson 2006 ILJ 704.

46 Section 1 of the LRA of 1956. Own emphasis added. 
and it established the boundaries of good and bad faith industrial action. ${ }^{47}$ So, for example, the IC in Commercial Catering and Allied Workers Union of SA $v$ Game Discount World Ltd ${ }^{48}$ confirmed the principle that temporary or tactical dismissals fell within the statutory definition of lock-outs. According to the IC such dismissals potentially had as their goal the purpose of persuading workers to accept a demand and were therefore immune to unfair labour practice scrutiny. However, it was deemed unacceptable to import the "final and irrevocable" dismissal, which did not advance collective bargaining, into the definition of lock-out. ${ }^{49}$ Consequently, the IC concluded that the final retrenchment of workers was unfair as it did not advance collective bargaining. On the other hand, it did permit temporary tactical dismissals as part of the collective bargaining process.

In an attempt to limit employees' actions and omissions covered in the shadows of lock-outs and operational dismissals, the then new LRA of 1995 's definition of lock-out was amended by removing all reference to dismissals. ${ }^{50}$ The definition now applies only to:

... the exclusion by an employer of employees from the employer's workplace, for the purpose of compelling employees to accept a demand. ${ }^{51}$

The LRA of 1995's definition of "lock-out" now apparently restricts employers' collective bargaining tools which could be used to strong-arm workers to accept a demand. The current definition also has the effect of expanding the CCMA and Labour Court's ("the LC") powers to find such dismissals, which do not fall within the realms of interest disputes,

47 National Union of Mineworkers v East Rand Gold and Uranium Co Ltd 1991 ILJ 1221 (A); Explanatory Memorandum Prepared by the Ministerial Legal Task Team 1995 ILJ 278, 289-299; Vettori 2005 De Jure 382.

48 Commercial Catering and Allied Workers Union v Game Discount World Ltd 1990 ILJ 162 (IC). Also see National Union of Metalworkers of SA v Aerial King Sales (Pty) (Ltd) 1994 ILJ 1384 (IC).

49 Thompson 2006 ILJ 727 mentions that the IC cases confirmed that temporarily dismissing employees "to induce compliance with an industrial demand was immune from unfair labour practice scrutiny, and in fact doing no worse than engaging in legitimate power-play". The cases "went on to strike down the cardinal sin of the time: the so-called 'termination lock-out' - permanent dismissals which employers wanted to smuggle into the protected lock-out stockade".

50 As aptly pointed out by the highest court in Ex Parte Chairperson of the Constitutional Assembly: In Re Certification of the Constitution of the Republic of South Africa, 19961996 ILJ 821 (CC) 841 in "South Africa the lock-out has been the subject of elastic statutory definition. Under the Labour Relations Act 28 of 1956, the lock-out was given wide definition to include a range of employer conduct aimed at compelling workers' agreement, including ... the dismissal of workers. The new Labour Relations Act 66 of 1995 ... gives a much more restricted definition of lockout".

51 Section 213 of the LRA of 1995. 
automatically unfair. As previously mentioned, section 187(1)(c) of the LRA of 1995 until the end of 2014 stated that it constitutes an automatic unfair dismissal should "the reason for the dismissal" of an employee be "to compel the employee to accept a demand in respect of any matter of mutual interest".

Disappointingly, policy makers failed to clarify the description of automatically unfair dismissal by explaining whether it aimed to proscribe: all dismissals associated with collective bargaining, only permanent dismissals as it was done by the IC, or the previously acceptable tactical dismissal of employees during the process of collective bargaining. This was an oversight and gave rise to the ensuing debate.

\section{$5 \quad$ Fry's Metals: Interpreting the former section 187(1)(c)}

In the Fry's Metals cases the employer's viability was placed under pressure by prevailing economic conditions. It sought to change conditions of service relating to its workers' shift system to ensure its survival. The employees rejected the proposed changes and the employer responded by notifying its workers that those who did not accept the amendments would be retrenched. This resulted in the applicant employees approaching the labour courts for an order interdicting the respondent employer from dismissing the employees.

In Fry's Metals, LC ${ }^{52}$ Francis AJ considered two questions in determining whether the dismissal constituted an automatically unfair dismissal. The first was whether the proposed changes constituted a "matter of mutual interest" as contemplated in the LRA of 1995 definition of automatically unfair labour practice. The second was whether the company's insistence on a new shift system sought to compel the employees to accept a demand in respect of a matter of mutual interest or, in the alternative, whether the company could legitimately implement the new shift system for operational reasons. ${ }^{53}$

The LC answered the first question in the affirmative, holding that the dispute involved "the creation of new rights or the diminution of existing rights" as per the conception of disputes of mutual interest. ${ }^{54}$ Having passed this hurdle, Francis $\mathrm{J}$ proceeded to find that the respondent had sought to avoid having to follow the path of conciliation and a subsequent lock-out to persuade the workers to accept its proposals. It elected to

National Union of Metalworkers of SA v Fry's Metals (Pty) Ltd 2001 ILJ 701 (LC).

Fry's Metals, LC paras 19-20.

Fry's Metals, LC para 28. 
conduct a lock-out dismissal and disguised it as a retrenchment which constituted an automatically unfair dismissal. ${ }^{55}$ The LC concluded that:

In the circumstances, the negotiations are seen as falling within what Professor Thompson calls the "wage work bargain" and as such I am reluctant to allow the dispute to escape the protected zone of collective bargaining in which dismissals of the present sort ought never to be permitted. ${ }^{56}$

On appeal the LAC followed a more nuanced, but problematic approach. Its main consideration was whether or not employers have a right to dismiss employees who are not prepared to agree to changes of their conditions of employment, when such changes are necessary for the viability, or improvement, of the employer's business. Zondo JP launched an enquiry into the relationship between the right to resort to retrenchment to survive or to improve profits, on the one hand, and on the other, an employee's right implicit in section 187(1)(c) not to be dismissed with the specific "purpose" of being compelled to agree to a demand in respect of a matter of mutual interest. 57

As the point of departure, the LAC accepted that there can be no doubt that section 188(1)(a)(ii) of the LRA of 1995 gives employers the right to dismiss workers for a reason based on its operational requirements. ${ }^{58}$ Zondo JP accorded a wide meaning to operational requirements dismissals and rejected the contention that the "survival of the business" is the sole criterion of substantive fairness. ${ }^{59}$ In principle, he held, an employer may also dismiss "if it is making profit and wants to make more profit". ${ }^{60}$ However, the LAC accepted that the conundrum comes in when, in terminating employees' contracts of employment, the employer is exercising his or her right to dismiss for operational reasons as opposed to

55 Fry's Metals, LC para 51 states that on the "facts of this matter, the employer clearly has invoked the threat of dismissal, in the guise of retrenchment, as a direct negative inducement to employees to abandon their reluctance to accept the new shift system. The threat of retrenchment of those employees who did not accede to the respondent's demand was made at a point in the negotiations where an impasse had been reached on these demands and was clearly prompted by the impasse. Before reaching this impasse in the negotiations, the respondent had no intention of, and had not contemplated, dismissing the employees".

56 Fry's Metals, LC para 54.

57 Fry's Metals, LAC para 1.

58 Fry's Metals, LAC para 22 emphasises ss 188(1)(a)(ii) and 67(5) of the LRA of 1995. The definition of "operational requirements" in $s 213$ of the LRA of 1995 is also scrutinised.

59 Fry's Metals, LAC paras 32-33.

60 Fry's Metals, LAC paras 32-33. 
dismissing in order to compel the employees to accept a demand as part of collective bargaining. ${ }^{61}$

In a somewhat surprising development, the LAC did not find a conflict in the automatically unfair dismissal and operational requirement provisions of the LRA of 1995. Rather than merely interpreting the sections of the LRA of 1995 as it stood, the LAC chose to second guess policy makers by finding that the prohibition contained in section 187(1)(c) of the LRA of 1995 was based on the LRA of 1956's historical definition of the term lockout, and Zondo JP relied on the decisions of the IC which delineated acceptable and unacceptable lock-out dismissals in the wake of collective bargaining.

However, this is where the LAC became misdirected. With reference to the IC's earlier judgment in Game Discount World ${ }^{62}$ the LAC first confirmed that under the old dispensation, for a dismissal to fall within the useful collective bargaining zone of the definition of a "lock-out", the dismissal had to have the purpose of compelling workers to accept a demand. In other words, it had to be temporary or strategic in nature to be protected. This, Zondo JP reasoned, was what the LRA of 1995 sought to prohibit under the auspices of automatic unfair dismissals. ${ }^{63}$

The LAC further reasoned that, due to the fact that final retrenchments, such as in this matter, did not fall under the former definition of lock-out, the Court was at liberty to hold that such terminations could be brought under permissible operational requirement dismissals under section 188 of the LRA of 1995.64

With reference to dismissal on the grounds of operational requirements, Zondo JP explained that the purpose of such terminations is to get rid of employees who do not meet the business requirements of the employer, so that new employees who will meet the business requirements can be employed. ${ }^{65}$ As such, the LAC found a distinct difference between an

61 Fry's Metals, LAC para 23.

62 Commercial Catering and Allied Workers Union v Game Discount World Ltd 1990 ILJ 162 (IC).

63 Fry's Metals, LAC paras 27.

64 Fry's Metals, LAC para 28 concluded that an employee's acceptance of an employer's demand in respect of a matter of mutual interest can be useful or worth anything only if the employee is going to continue in the employer's employ. The reason for this is that after an employee is finally dismissed, no employment relationship exists between the parties. Fry's Metals, LAC para 30. 
automatically unfair dismissal and a dismissal based on operational requirements. ${ }^{66}$ The former is prohibited, and the latter is not.

In our opinion the LAC decision was wrong for a number of reasons. Firstly, the post-constitutional LRA of 1995's definition of lock-out was amended to exclude all forms of dismissal. It was, therefore, inappropriate for Zondo JP to continue relying on the IC decisions which related to the dividing line between the permissible and impermissible types of dismissal in the new era. Secondly, the Game Discount World case concluded that permanent dismissals were unfair in the context of collective bargaining, but that strategic dismissals were acceptable. Had the facts of the Fry's Metal case been considered by the IC it would undoubtedly have made an adverse finding against the employer in so far as the final dismissals would have eroded the institution of collective bargaining. Third, it is inconceivable that the LAC could find only the lesser form of termination the strategic one, where workers could still potentially retain their jobs if they were to give in to the demands of the employer - to be covered by the definition of automatic unfair dismissal, but not irreversible retrenchments. The acceptance of this argument undermines the very structure of collective bargaining, and it is contended that it is highly unlikely that the legislature intended section 187(1)(c) of the LRA of 1995 to have such an effect.

This steered the LAC to conclude that the protection against automatically unfair dismissals applied to any dismissal that was the result of the failure by the affected employees to accept a demand made by the employer relating to an aspect of mutual interest to the employer and the employees. However, the LAC excluded from the ambit of protection a decision by an employer which finally terminates contracts of employment as part of a retrenchment exercise. ${ }^{67}$

The Fry's Metals cases reached finality in the SCA in 2005.68 Mpati DP and Cameron JA recognised the fact that competing interests are

66 According to the LAC Fry's Metals, LAC para 31 the distinction is made as follows: Either the dismissal is effected in order to compel the employees to agree to the employer's demand, and the dismissal would be withdrawn and the employees retained if they accept the demand, or the dismissal is final so that, in a case like this one, the employer may replace the employees permanently with employees who are prepared to work under the terms and conditions that meet the employer's requirements.

67 Fry's Metals, LAC para 27 held that "what was said by the Industrial Court in Game Discount World in respect of a lock-out dismissal under the definition of a lock-out under the old Act, namely, that such a dismissal cannot be final and irrevocable, applies with equal force to the provisions of $s$ 187(1)(c) of the Act".

68 National Union of Metalworkers of South Africa v Fry's Metals (Pty) Ltd 2005 ILJ 689 (SCA). 
protected by the LRA of 1995 . While it is one of the primary aims of the LRA of 1995 to protect and encourage collective bargaining between workers and employers ${ }^{69}$ it does on the other hand permit employers to effect changes to conditions of service justified by operational requirements. ${ }^{70}$ The SCA scrutinised what they referred to as an "influential article" by Thompson alluded to above but rejected his line of reasoning. In his article, Thompson bases his argument on the premise that the LRA of 1995's framework is based on a distinction between disputes of right and disputes of interest. He reasons that dismissals on the ground of operational requirements should never be permitted in the arena of collective bargaining to coerce workers to accept a demand. However, it is permissible only in respect of disputes of business restructuring where the viability of the business is at stake. In this category of operational requirements dismissals, which are rights based, there is an overlap with collective bargaining or interest based disputes. He further suggests that only in instances where a dispute has "migrated", from the collective bargaining to the rights based domain should it be permissible to dismiss workers. ${ }^{71}$ However, he argues that this should not be permitted randomly and effortlessly. The courts should scrutinise the issue on a case-by-case basis, and only where an employer could show a "demonstrably sensible business analysis" that the dismissal is acceptable where a dispute had drifted from the domain of interest to rights disputes. $^{72}$

The SCA rejected Thompson's arguments and Mpati DP and Cameron JA reasoned that:

The core difficulty with this argument is that the dichotomy between matters of mutual interest and questions of "right" do not in our view form the basis of the collective bargaining structure that the statute has adopted. The unavoidable complexities that arise from the supposed "migration" of matters of mutual interest to matters of "right" demonstrate in our view that the dichotomy does not form the basis of the statutory structure, and $s$ 187(1)(c) cannot, accordingly, be interpreted as if the legislation proceeds from that premise. ${ }^{73}$

The SCA concluded by supporting the LAC decision in so far as the enquiry into section $187(1)$ (c) of the LRA of 1995 should start with the

69 Fry's Metals, SCA. It was confirmed (para 52) that on "the other hand the statute is at pains to erect a system that scrupulously protects and encourages collective bargaining between workers and employers, so as to facilitate the conclusion of collective agreements, which are defined as written agreements concerning terms and conditions of employment or any other matter of mutual interest".

70 Fry's Metals, SCA para 51. The SCA refers to ss 67, 188 and 189 of the LRA of 1995.

71 Fry's Metals, SCA para 51. Reference is made to Thompson 1999 ILJ 770.

72 Fry's Metals, SCA para 51. Reference is made to Thompson 1999 ILJ 770.

73 Fry's Metals, SCA para 54. 
meaning of "dismissal" which permits termination, with or without notice, on the grounds of misconduct and operational requirements. ${ }^{74}$ According to the SCA, the "two categories do not overlap" as there is a difference between such dismissals and automatically unfair dismissals, which must be effected for the purpose of compelling employees to accept a demand. ${ }^{75}$ In this instance the employer sought to dismiss employees on operational grounds and the application for leave to appeal was dismissed.

The decision of the SCA is open to the same criticism as that levelled against the LAC decision to which we alluded to above. However, in addition, we have two main points of criticism against Mpati DP and Cameron JA's judgment. Firstly, the SCA was misdirected in finding no contradiction, or at least an eroding effect, between the statutory provisions which permit dismissal on the grounds of operational requirements and terminations by reason of compelling employees to accede to an employer's demand. We agree with Thompson that there are grey areas where operational requirement dismissals and strategic dismissals which form part of collective bargaining overlap. This is so, particularly where an employer has its proverbial back against the wall and is fighting for its financial survival. Rather than admitting that such a shadowy area exists, and assuming the responsibility of evaluating on a case-by-case basis where there are substantive reasons to endorse such dismissal, the SCA stuck to the structured divide between strategic and permanent dismissals. The SCA also completely missed the point made in the Game Discount World case in which it was held that permanent dismissals ought to be prohibited on the ground of unfairness and that temporary dismissals could be acceptable.

Secondly, the SCA erred by contending that the structure of the LRA of 1995 has nothing to do with the divide between disputes of interest and disputes of right. Yes, the LRA of 1995 does not specifically employ the terms disputes of "interest" and questions of "right", but there can be no doubt that the broad dispute resolution structure is grounded on the resolution of interest disputes through collective bargaining, strikes and lock-outs, and disputes of right through arbitration and adjudication. It is no coincidence that section 65(1)(c) of the LRA of 1995 provides that:

$$
\text { No person may take part in a strike or lock-out ... if ... }
$$

74 "Dismissal" is defined in s 186(1) of the LRA of as meaning, among other things, that "(a) an employer has terminated a contract of employment with or without notice".

75 Fry's Metals, SCA para 55. 
(c) the issue in dispute is one that a party has the right to refer to arbitration or to the Labour Court in terms of the Act.

Notwithstanding our reservations about the Fry's Metals decisions, these precedents had a substantial effect and following in subsequent labour jurisprudence. ${ }^{76}$ The situation remained unchanged until the implementation of the LRAA of 2014 on 1 January 2015.

\section{The Labour Relations Amendment Act of 2014}

\subsection{Amendment to section 187(1)(c)}

In an attempt to remedy the incongruities referred to above, the LRAA of 2014 amended section 187(1)(c) of the LRA of 1995 to read that:

... a dismissal is automatically unfair if the reason is a refusal by employees to accept a demand in respect of any matter of mutual interest between them and their employer.

The only difference between the previous definition and the current definition is that the old section's words, "to compel the employee to accept a demand", have been replaced by the phrase "is a refusal by employees to accept a demand".

The Memorandum of Objects: Labour Relations Amendment Bill, 2012, which gives background to the LRAA of 2014, does not clarify what policy considerations underlie the amendment. It fails to explain whether the amendment has as a purpose to extend the scope of automatic unfair

76 In addition to older cases such as Mazista Tiles (Pty) Ltd $v$ National Union of Mineworkers 2004 ILJ 2156 (LAC) and Algorax, later cases continue to endorse the principles laid down in Fry's Metals. See, for example, BEMAWU obo Mohapi v Clear Channel Independent (Pty) Ltd 2010 ILJ 2863 (LC) paras 26-29. The LC held that there "seems to be no doubt that an employer can in law utilise the principles of operational requirements to terminate the employment of an employee who refuses to accept the changes to terms and conditions of employment. However, a dismissal based on operational requirements would be automatically unfair if no valid operational requirements exist to justify changes and also as indicated earlier the dismissal is not final and intended to replace an employee with those who may be willing to accept the changes in the conditions of employment". In a similar fashion, the LC in Solidarity obo Wehncke v Surf4cars (Pty) Ltd 2011 ILJ 3037 (LC) para 11. The LC held that "even if the conditions attaching to company car usage had amounted to an alteration of the applicant's orally agreed terms of employment, his dismissal was not conditional in the narrow sense meant by the Supreme Court of Appeal in Fry's Metals. Nothing in the applicant's statement of case ... shows that the respondent made it clear that he would be reinstated if he signed the contract". Also in Michael Peter Wilkin v Warwick Invest (Pty) Ltd 2013 ZALCCT 10 (30 April 2013) paras 9, 12 the LC confirmed that this "provision has been interpreted by the Labour Appeal Court and Supreme Court of Appeal to confer limited protection - it applies if and only if the employer uses dismissal as a weapon to secure agreement to new terms and conditions of employment where the employer's purpose is to effect a dismissal that is reversible on accession by the employee to the employer's demand. On the facts disclosed by the stated case before me the applicant's dismissal was unconditional and irreversible". 
dismissal to remove the distinction which has been drawn in the Game Discount World case and the Fry's Metals cases between strategic and permanent dismissals. It also does not say whether it has the intention of extending protection to employees, namely by covering all dismissals associated with the negotiation of matters of mutual interest; even if it occurs when a business is faced with economic extinction.

The only clues that can be derived from the Memorandum of Objects: Labour Relations Amendment Bill, 2012 are that the amendment aims to remove the anomaly arising from the Fry's Metals' interpretation of the definition of automatically unfair dismissal, and to give effect to the intention of the provision as enacted in 1995, which seeks to protect the integrity of the process of collective bargaining. ${ }^{77}$

Going back to the intention of the policy maker that prevailed in 1995, the Explanatory Memorandum Prepared by the Ministerial Legal Task Team, $1995^{78}$ did not expand on the intention behind the removal of dismissal from the definition of lock-out or the inclusion of the definition of automatic unfair labour practice. However, the document does explain what it intended in the difficult area of collective bargaining in the face of the eradication of a business due to financial hardship:

Where the strike conforms with the provisions of the draft Bill there is an absolute prohibition on the dismissal of strikers. ... Careful consideration was given to allowing an employer to dismiss where there may be irreparable harm caused by the strike. ... The draft Bill offers the employer facing bankruptcy three options -

- resolve the dispute;

- employ alternative labour;

- dismiss on grounds of operational requirements. ${ }^{79}$

It is disquieting that this focus on insolvency and operational requirement dismissals never made its way into the LRA of 1995. In his contribution Thompson writes that if one were to ask "many in the trade union leadership" what the original intention behind section 187(1)(c) of the LRA of 1995 was, they would say that all matters of mutual interest "should be determined solely by the collective bargaining process" and if, with their available collective bargaining weaponry

77 Memorandum of Objects: Labour Relations Amendment Bill, 2012 17. Emphasis added.

78 Explanatory Memorandum Prepared by the Ministerial Legal Task Team 1995 ILJ 278.

79 Explanatory Memorandum Prepared by the Ministerial Legal Task Team 1995 ILJ 305. 
... employers cannot induce acceptance of their demands for altered terms and conditions of employment, then the status quo must live on. ${ }^{80}$

But this, according to Thompson, would not "serve industrial society well". ${ }^{81} \mathrm{He}$ suggested that it should be permissible for disputes to migrate from the collective bargaining sphere (disputes of interest) to questions of right in instances where the employer's decision has been formulated on a "sensible business analysis that has been probed in the consultative process". 82

We argue that the absence of this qualification results in uncertainty in this area of the law and leaves the clash between sections 188(1) and 187(1)(c) of the LRA of 1995 exposed.

\subsection{Effect of the amendment on the Fry's Metals dichotomy}

Even though it is not clearly stated, the amendment appears to be at pains to shift the focus away from the employer's intention behind the dismissal to compel employees to accept a demand. Therefore, the ambit of automatically unfair dismissal has thus been extended to cover all situations where employees are dismissed for refusing to accept amendments to their conditions of service, irrespective of the employer's intent. ${ }^{83}$ Grogan fittingly states that the effect of this amendment is that an automatically unfair dismissal now occurs simply because the employer has made a demand which the employees refused to accept. It has become irrelevant whether or not the dismissal or threat thereof was intended to induce the employees to comply. ${ }^{84}$

Does the amendment resolve the issues which emerged in the Fry's Metals cases? Remember that here, both the LAC and SCA placed a great deal of emphasis on whether or not the employer intended to compel or coerce the employees to accede to a demand. ${ }^{85}$ If this was not the case, such as in the event of the permanent termination on the ground of operational requirements, these dismissals fell beyond the scope of automatically unfair dismissals. The upshot of this was that it could, potentially so, be deemed to be a fair termination under the provisions of

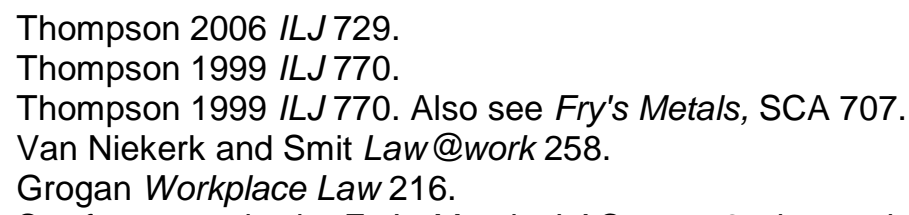

So, for example, in Fry's Metals, LAC para 27 it was held that a "dismissal must have as its purpose the compulsion of the employees concerned to accept a demand in respect of a matter of mutual interest between employer and employee. If a dismissal is not for that purpose, it falls outside the ambit of $s$ 187(1)(c)". 
operational requirements dismissals. ${ }^{86}$ On this basis the LAC concluded that if a dismissal is final the purpose cannot be to compel workers to accept a demand which falls in the ambit of disputes of interest. ${ }^{87}$

To us, it is clear that had the amended section been in place at the time of the Fry's Metals decisions, the LAC's and SCA's reasoning would not have prevailed, as there would have been no question as to whether or not the purpose or reason for the dismissal was to compel the employees to accept a demand. Instead it would have resulted in a decision that the dismissals were impermissible on the ground of their being automatically unfair, irrespective of whether they were permanent or temporary dismissals.

However, this does not resolve the entire issue. Whilst the amendment eliminates the distinction drawn by the LAC and the SCA between conditional and final dismissals, the important question remains whether it is still permissible at all for an employer to dismiss employees on operational grounds should they refuse to accede to the employer's demands for amendments to their conditions of service. Would it, for example, be possible for an employer who is facing economic capitulation to enter negotiations with employees about the amendment of their conditions of employment to save a sinking ship? It is instructive that the Memorandum of Objects: Labour Relations Amendment Bill, 2012 makes no mention of the approach of the Explanatory Memorandum Prepared by the Ministerial Legal Task Team, 1995 that operational requirement dismissals should be permissible when an employer is facing bankruptcy. ${ }^{88}$

\subsection{Can an employer still dismiss for operational requirements?}

In our view, there is a crossing point between collective bargaining and operational requirements dismissals where the provisions of the LRA of 1995 clash. This aspect which the Fry's Metals cases had to deal with has

86 Sections 188(1) and 189 of the LRA of 1995.

87 Fry's Metals, LAC para 35 took heed of the manner in which the respondents set out the basis of their challenge against the dismissals. The LAC held that the respondents did not in their founding affidavit allege that in dismissing the employees, the appellant sought to compel them to agree to the changes it was proposing. The Court went on to hold that the respondents instead, alleged that the appellant was proposing to dismiss the employees as a result of their failure to agree to changes to their terms and conditions of employment. This, the court held, was not the same. 278305. 
not been resolved by the LRAA of $2014 .{ }^{89}$ After the amendment, the provisions in the LRA of 1995 which regulate dismissals for operational requirements remain unchanged. The definition of "operational requirements" 90 has not been qualified to indicate that such dismissals are no longer permissible where employees refuse to accept a demand in respect of a matter of mutual interest. Nor have policymakers released employers from their statutory obligation to "engage in a meaningful joint consensus-seeking process in an attempt to reach consensus" about measures to "avoid", "minimise" or "mitigate" the number of dismissals before proceeding with dismissals on the ground of operational requirements. ${ }^{91}$ This could arguably include changing conditions of service during the process of dismissal on the ground of operational requirements to ensure the survival of a business.

Another overlooked aspect is the fact that policymakers continue to endorse the right of an employer to dismiss employees participating in a protected strike for reasons based on the employer's operational requirements. ${ }^{92}$ The right to strike forms an integral and uncontested element of disputes of interest and collective bargaining. ${ }^{93}$ In South African Chemical Workers Union $v$ Afrox, ${ }^{94}$ Landman $\mathrm{J}$ of the LC explicitly recognised that there are two exceptions to the prohibition on the dismissal of workers engaged in a protected strike action, the first misconduct, and the second relating to the economic foundations of employment. Here, Landman J held that:

Although we may speak of the right to a job, this right is itself dependent, at least in the private sector, on the existence in economic terms of the enterprise. The enterprise which provides the employment must maintain its way, grow and prosper for the right to a job to have a meaning. If it fails then the right to a job fails with it. Economics dictates that if it is necessary to shed jobs so that the enterprise may survive or alter or adapt its business

89 Grogan 2003 ELL 6 further states that "Fry's Metals, therefore, illustrates a classic conflict between the employer's right to dismiss for operational requirements (provided, of course, a fair procedure is followed) and the employee's right not to be dismissed in order to be induced to comply with an employer's demand".

90 Section 213 of the LRA of 1995.

91 Section 189(2) of the LRA of 1995. In our view, such consultations are closely related to the process of collective bargaining.

92 Section 67(5) of the LRA of 1995 provides that the LRA of 1995 does "not preclude an employer from fairly dismissing an employee" engaged in a protected strike for "a reason based on the employer's operational requirements".

93 NUMSA v Bader Bop (Pty) Ltd 20032 BLLR 103 (CC). It was held (para 67) that the "right to strike is essential to the process of collective bargaining. It is what makes collective bargaining work. It is to the process of bargaining what an engine is to a motor vehicle".

94 South African Chemical Workers Union v Afrox Ltd 1998 ILJ 62 (LC). This point of view was endorsed by the LAC in SA Chemical Workers Union v Afrox Ltd 1999 ILJ 1718 (LAC) para 29. 
then so be it. This basic economic premise has been incorporated in the Act by way of the exception permitting dismissal for operational requirements. ${ }^{95}$

Although this case concerned the dismissal of striking workers for operational requirements, it is relevant to the topic under discussion, as like the question being analysed in this instance, it involved the use of a rights-based remedy (dismissal) to address issues that were the subject of collective bargaining (an interest-based dispute). ${ }^{96}$

This illustrates that notwithstanding the undisputed importance of collective bargaining, economic circumstances cannot be ignored. The law needs to be implemented in a manner that recognises the commercial principle which accepts that the need may be justified to dismiss employees where the survival of the business is at stake. As fittingly pointed out by Todd and Damant, although distributive issues which impact on the economic viability and success of an enterprise may initially form the subject of collective bargaining, it may in time become the subject of retrenchments. ${ }^{97}$ Despite the problems which the SCA in the Fry's Metals ${ }^{98}$ case had with the migration of disputes, it is evident that while there is a large degree of separation between rights and interest disputes, there are instances where they intersect. ${ }^{99}$ One example is collective bargaining and dismissal for operational requirements. ${ }^{100}$

Taking account of statutory provisions which direct employers to participate in "a meaningful joint consensus-seeking process in an attempt to reach consensus" before employees may be retrenched and the right to dismiss on operational requirements during a protected strike, it is doubtful that the purpose of the current section 187(1)(c) of the LRA of 1995 is to

95 SA Chemical Workers Union v Afrox Ltd 1999 ILJ 1718 (LAC) para 66.

96 With reference to the subsequent appeal case Cohen 2004 ILJ 1895 alludes to the fact that in "Afrox the Labour Appeal Court confirmed that in some cases, where the employer is faced with economic collapse as a result of a strike, it may be fair to use retrenchment to conform interest disputes into rights disputes. Similarly in the context of a restructuring exercise, which is essentially an interest dispute and which must commence at the bargaining arena, it may become necessary to resort to retrenchment dismissals when collective bargaining fails".

97 Todd and Damant 2004 ILJ 912.

98 Fry's Metals, SCA. It was held (para 59) that "[i]n our view neither s 187(1)(c) nor the collective bargaining structure of the statute as a whole contemplates the 'migration' of disputes from one part of the LRA's taxonomy to another".

99 Todd and Damant 2004 ILJ 913. The authors confirm that "[n]o conceptual distinction can properly be drawn between matters of mutual interest and the 'matters' that cause employers to contemplate retrenchments. All of these matters impact ultimately on the 'wage-work bargain' and should (or may) be discussed in the same process of engagement between management and labour. It is therefore artificial to talk of the 'migration' of engagement from the arena of bargaining to the arena of dismissal".

100 Van Niekerk and Smit Law@work 446. 
outlaw dismissals for operational requirements in totality. However, what policy makers failed to do during the latest round of amendments, was to provide clarity about when these dismissals may still be acceptable. ${ }^{101}$

It should, however, be stressed that the approach alluded to above, which confirms that operational requirements dismissals in the wake of collective bargaining have not been abolished, does not imply that it can be followed in every situation where employees refuse to agree to proposed changes. The central question that needs to be answered is whether the reason for the dismissal is due to the refusal by the employees to accept the proposed demand, or whether it is based on genuine operational reasons. ${ }^{102}$

There is the counter-argument to the right to dismiss on the grounds of operational requirements based on the proposition that there is adequate machinery provided for in the LRA of 1995 to resolve interest disputes. ${ }^{103}$ We disagree with this. Firstly, the option for employers to rely on the lockout as a collective bargaining tool was watered down in the LRA of 1995 as the definition of lock-outs was amended to exclude all forms of dismissal.

Secondly, employers taking the initiative in collective bargaining are precluded from relying on replacement labour during lock-outs. ${ }^{104}$ Replacement workers may be relied on only if employers lock-out in response to a strike. ${ }^{105}$

With the implementation of the LRAA of 2014, the legislature has made no attempt to formulate a new equilibrium within the collective bargaining framework for employers and employees which may have provided room for abolishing operational requirement dismissals in the context of

101 Du Toit et al Labour Relations Law 435-436. Also see Van Niekerk and Smit Law@work 258, where it is stated that if "the employer dismisses because the employee refuses to accept a changed shift configuration, there seems to be nothing to preclude the employer from dismissing the employee for a reason related to its operational requirements if its true intention is to replace employees with others who are willing to work according to the new configuration".

102 In Mazista Tiles (Pty) Ltd v National Union of Mineworkers 2004 ILJ 2156 (LAC) para 48. The LAC indicated that where employees refuse to accept proposed changes to terms and conditions of employment, this does not mean that the employer can never effect the desired changes. While it is impermissible to dismiss in order to compel employees to accept a demand, the employer has the right to invoke the provisions of $\mathrm{s} 189$ provided the necessary requirements of the section are met.

103 So for example, Fry's Metals, LC para 37. Here the employer is criticised for avoiding implementing a lock-out to persuade its employees to accede to its demands.

104 Section 76(1)(a) of the LRA of 1995. Technikon SA v NUTESA 20011 BLLR 46 (LAC).

105 Section 76(1)(b) of the LRA of 1995. 
collective bargaining. Considering the current structure of the LRA of 1995, with all of its permissible weaponry, an interpretation of automatic unfair dismissal that disallows dismissals for operational requirements in its totality is not sustainable and disavows business imperatives in an increasingly competitive environment.

\subsection{The impact of section 187(1)(c) on dismissals for increased profits}

While it has been argued that in principle the purely profit-enhancing reduction of staff fell foul of the former section 187(1)(c) of the LRA of $1995,{ }^{106}$ the LAC in Fry's Metals found that the LRA of 1995 does not distinguish between dismissals for operational reasons intended to save a business from failure and those intended simply to increase profitability. As alluded to by Zondo JP:

This is because all the Act refers to, and recognises, in this regard is an employer's right to dismiss for a reason based on its operational requirements without making any distinction between operational requirements in the context of a business the survival of which is under threat and a business which is making profit and wants to make more profit. ${ }^{107}$

This approach was accepted by Nicholson JA in General Food Industries $v$ FAWU when he held:

I am of the view that a natural consequence of the Fry's Metals judgment is that, all things being equal, a company is entitled to insist by economic restructuring that a profitable centre becomes even more profitable. The Act recognises an employer's right to dismiss for a reason based on its operational requirements without making any distinction in the context of a business the survival of which is under threat and a business which is making profit and wants to make profit. ${ }^{108}$

It is clear that there has been no change to the definition of operational requirements in section 213 of the LRA of 1995 and the previous pronouncements by the LAC continue to be relevant in 2016. ${ }^{109}$

However, the expansive interpretation of operational requirement dismissals can have detrimental consequences if not dealt with appropriately. It is for this reason that the courts have a crucial role to play

106 Thompson 1999 ILJ 766.

107 Fry's Metals, LAC para 33 held "that neither Thompson in his article nor counsel in his argument has pointed to any provision in the Act that can be relied upon to make this distinction". Also see Mazista Tiles (Pty) Ltd v National Union of Mineworkers 2004 ILJ 2156 (LAC) para 57.

108 General Food Industries Ltd v Food and Allied Workers Union 2004 ILJ 1260 (LAC) para 52.

109 See, for example, South African Transport and Allied Workers Union v G4S Aviation Secure Solutions 2016 ZALCJHB 10 (13 January 2016) paras 21-22. 
in unearthing the true reason for the dismissal and ensuring that fairness prevails. In this regard, Du Toit ${ }^{110}$ points out that:

\begin{abstract}
... though the notion of employers being free to dismiss workers "merely to increase profit" may seem to open the floodgates to dismissal virtually at will, the causal nexus between a dismissal and the employer's operational needs must still pass the test of fairness. The real question remains: will it be fair in the given circumstances to dismiss employees in order to increase profit or efficiency? ${ }^{111}$
\end{abstract}

As previously indicated, the line between an automatically unfair dismissal for refusing to accept changed terms and conditions of employment and a legitimate dismissal on the grounds of an employer's operational requirements will often be a fine one. There can be no doubt that the responsibility to determine where the line should be drawn on a case-bycase basis continues to rest on the shoulders of the labour courts. ${ }^{112}$

\title{
$7 \quad$ The appropriate test and concluding remarks
}

There is a need to allow for the use of dismissals in certain instances where there is a refusal to accept proposed changes to the terms and conditions of employment. The scheme of the LRA of 1995 accommodates this, and a holistic consideration of all the relevant sources of law, as discussed in this article, finds no authority to suggest that section $187(1)$ (c) in its current form should not be interpreted in a manner that permits the use of operational requirement dismissals.

However, this should by no means give employers carte blanche in utilising this remedy. It would be imprudent to trust that this avenue will always be used in a conscientious and apposite manner, especially considering that it is justifiable to dismiss for operational requirements in order to become more profitable. As such, the courts play an essential role in ensuring that fairness prevails, and that disguised retrenchments do not take place within the employment arena where collective bargaining should prevail. Fairness has become the hallmark, or essence, of labour

110 Du Toit 2005 ILJ 602 confirms that the "term operational requirements, as defined in $s$ 213, is broad enough to include every conceivable business consideration that might lead an employer to consider dismissal in the context of restructuring" and this could even include the quest to increase profits.

111 Du Toit 2005 ILJ 606. Also see at 602, where Du Toit states that the word "fair" introduces the following vital qualification: "Though seldom considered explicitly by the courts and frequently taken for granted, it is this concept - rather than the presence or absence of an operational basis for the employer's decision - that lies at the heart of most disputes about substantive fairness".

112 Van Niekerk and Smit Law@work 258. 
law and practice and it does not merely serve as a moral adjunct thereto. ${ }^{113}$ As aptly captured by Thompson: ${ }^{114}$

[t] he courts ... should regard the operational requirements claim with a healthy measure of scepticism, and use the fairness filter to sort the chaff from the corn.

We contend that the courts are compelled to apply an objective test in their quest to determine fairness in the narrow permissible zone of dismissals in the context of collective bargaining. ${ }^{115}$ As confirmed by Zondo JP in Algrorax, when courts are seized with a dismissal dispute, the court must determine the fairness of the dismissal objectively and:

... must not defer to the employer for the purpose of answering that question. In other words it cannot say that the employer thinks it is fair, and therefore, it is or should be fair. ${ }^{116}$

It is our view that the test which the LAC applied in SA Chemical Workers Union $v$ Afrox $L t d^{117}$ in determining the true reason for the dismissal in the context of strikes and retrenchments is also the appropriate test to be applied in the intersection between automatically unfair and operational requirement dismissals. Froneman DJP stated that the courts must:

\begin{abstract}
... determine factual causation: was participation or support, of the protected strike a sine qua non (pre-requisite) for the dismissal? Put another way, would the dismissal have occurred if there was no participation or support of the strike? If the answer is yes, then the dismissal is not automatically unfair. If the answer is no, that does not immediately render the dismissal automatically unfair; the next issue is one of legal causation, namely whether such participation or conduct was the "main" or "dominant", or "proximate", or "most likely" cause of the dismissal. ${ }^{118}$
\end{abstract}

In applying this test to section 187(1)(c) of the LRA of 1995, the question that must be asked is whether the dismissal would have occurred if there had been no refusal by the employees to accept the demand proposed by the employer. If the answer is yes, the dismissal is not automatically unfair. If the answer is no, then one would proceed to the issue of legal causation in order to determine whether the refusal by the employees was or was not the most likely cause of the dismissal. In answering this question, the facts and circumstances of the dismissals will have to be

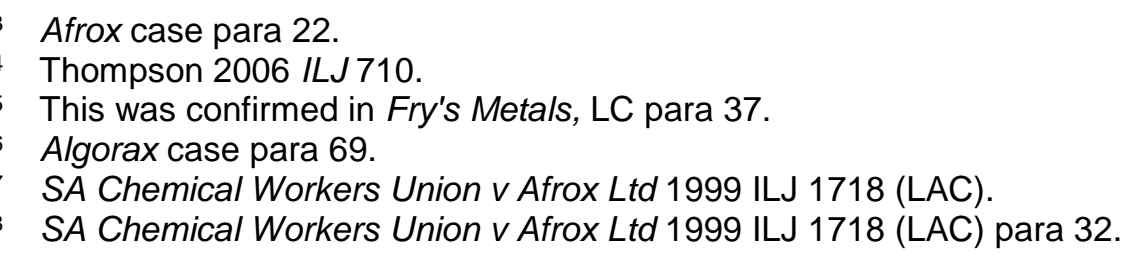


objectively assessed and evaluated in order to establish the most probable inference that can be drawn. ${ }^{119}$

The legislature can be criticised for not being more articulate about the purpose of the amendment of section 187(1)(c) of the LRA of 1995. Such clarification would have been apt against the background that no amendments were made to the provisions which permit operational requirement dismissals. The continued obscurity could readily have been removed by including further detail in the wording of the LRA of 1995 or the Code on Dismissal Based on Operational Requirements.

The amended provision could have clarified that a dismissal is automatically unfair if the reason for the dismissal is a refusal by employees to accept a demand in respect of any matter of mutual interest between them and their employer. However, this does not preclude dismissals for operational requirements, which are dealt with and permitted in further sections of the LRA of 1995. In addition to this, the policymakers should have considered giving effect to the suggestions made in the Explanatory Memorandum Prepared by the Ministerial Legal Task Team, 1995 in order to narrow the scope of permissible operational requirements in the context of collective bargaining. Legitimate retrenchments could have been limited to exclude instances where the employer seeks to improve profits, but to cover instance where employers are warding off insolvency.

Even in the absence of these suggested amendments, it is suggested that the principle that employers are permitted to retrench employees with a view to increasing profits should be reassessed with a healthy measure of scepticism. It is suggested that such a retrenchment should be permitted only if an employer is able to discharge a higher level of proof and scrutiny. The courts should not shy away from their responsibility of determining fairness - even if this entails second guessing employers' business decisions.

119 Case law illustrates that courts are playing an interrogative role in this regard. In South African Transport and Allied Workers Union v G4S Aviation Secure Solutions 2016 ZALCJHB 10 (13 January 2016) para 22 the court considered the arguments and evidence that were adduced that the employer acted in bad faith when effecting the retrenchments, or that it had sought to serve an ulterior motive. However, on the evidence the court could find no reason to indicate that the decision of the employer was not commercially rational. A similar approach was followed in South African Commercial and Catering Workers Union obo $J$ Bheki v Entabeni Private Game Lodge (Pty) Ltd 2015 ZALCJHB 410 (18 November 2015); Bifawu \& SACCAWU obo PV Mpanza v Zurich Insurance Company South Africa 2015 ZALCJHB 141 (23 April 2015). 


\section{Bibliography}

\section{Literature}

Cohen 2004 ILJ

Cohen T "Dismissals to Enforce Changes to Terms and Conditions of Employment - Automatically Unfair or Operationally Justifiable?" 2004 ILJ 1883-1896

Du Toit 2005 ILJ

Du Toit D "Business Restructuring and Operational Requirements Dismissals: Algorax and Beyond" 2005 ILJ 595-617

Du Toit et al Labour Relations Law

Du Toit D et al Labour Relations Law: A Comprehensive Guide $6^{\text {th }}$ ed (LexisNexis Durban 2015)

Grogan 2003 ELJ

Grogan J "Chicken or Egg" 2003 ELJ 4-12

Grogan Workplace Law

Grogan J Workplace Law $11^{\text {th }}$ ed (Juta Cape Town 2014)

Mischke 2003 CLL

Mischke C "Changing Terms and Conditions of Employment: The Return of the Automatically Unfair Dismissal" 2003 CLL 31-37

Qotoyi and Van Der Walt 2009 Obiter

Qotoyi T and Van Der Walt A "Dismissals within the Context of Collective Bargaining" 2009 Obiter 63-119

Thompson 1999 ILJ

Thompson C "Bargaining, Business Restructuring and the Operational Requirements Dismissal" 1999 ILJ 755-772

Thompson 2006 ILJ

Thompson C "Bargaining Over Business Imperatives: The Music of the Spheres After Fry's Metals" 2006 ILJ 704-730

Todd and Damant 2004 ILJ

Todd C and Damant G "Unfair Dismissal - Operational Requirements" 2004 ILJ 896-922

Van Niekerk and Smit Law@work

Van Niekerk A and Smit N Law@work $3^{\text {rd }}$ ed (LexisNexis Durban 2015)

Vettori 2005 De Jure

Vettori S "A Judicially Enforceable Duty to Bargain?" 2005 De Jure 382 


\section{Case law}

BEMAWU obo Mohapi v Clear Channel Independent (Pty) Ltd 2010 ILJ 2863 (LC)

Bifawu \& SACCAWU obo PV Mpanza v Zurich Insurance Company South Africa 2015 ZALCJHB 141 (23 April 2015)

Chemical Workers Industrial Union v Algorax (Pty) Ltd 2003 ILJ 1917 (LAC)

Commercial Catering and Allied Workers Union v Game Discount World Ltd 1990 ILJ 162 (IC)

De Beers Consolidated Mines Ltd v CCMA 20005 BLLR 578 (LC)

Ex Parte Chairperson of the Constitutional Assembly: In Re Certification of the Constitution of the Republic of South Africa, 19961996 ILJ 821 (CC)

Fry's Metals (Pty) Ltd v National Union of Metalworkers of SA 2003 ILJ 133 (LAC)

General Food Industries Ltd v Food and Allied Workers Union 2004 ILJ 1260 (LAC)

Mazista Tiles (Pty) Ltd v National Union of Mineworkers 2004 ILJ 2156 (LAC)

Michael Peter Wilkin v Warwick Invest (Pty) Ltd 2013 ZALCCT 10 (30 April 2013)

National Union of Metalworkers of SA v Aerial King Sales (Pty) (Ltd) 1994 ILJ 1384 (IC)

National Union of Metalworkers of SA v Fry's Metals (Pty) Ltd 2001 ILJ 701 (LC)

National Union of Metalworkers of SA v Fry's Metals (Pty) Ltd 2005 ILJ 689 (SCA)

National Union of Mineworkers $v$ East Rand Gold and Uranium Co Ltd 1991 ILJ 1221 (A)

Ntimane $v$ Agrinet 19993 BLLR 248 (LC)

NUMSA v Bader Bop (Pty) Ltd 20032 BLLR 103 (CC)

SA Chemical Workers Union v Afrox Ltd 1999 ILJ 1718 (LAC)

SACTWU v Stuttafords Department Stores Ltd 1999 ILJ 2692 (LC)

Solidarity obo Wehncke $v$ Surf4cars (Pty) Ltd 2011 ILJ 3037 (LC)

South African Chemical Workers Union v Afrox Ltd 1998 ILJ 62 (LC) 
South African Commercial and Catering Workers Union obo $J$ Bheki $v$ Entabeni Private Game Lodge (Pty) Ltd 2015 ZALCJHB 410 (18 November 2015)

South African Transport and Allied Workers Union v G4S Aviation Secure Solutions 2016 ZALCJHB 10 (13 January 2016)

Stuttafords Department Stores Ltd v SACTWU 20011 BLLR 46 (LAC)

Technikon SA v NUTESA 20011 BLLR 46 (LAC)

\section{Legislation}

Labour Relations Act 28 of 1956

Labour Relations Act 66 of 1995

Labour Relations Amendment Act 6 of 2014

\section{Government publications}

Code on Dismissal Based on Operational Requirements (Gen N 1517 in GG 20254 of 16 July 1999)

Explanatory Memorandum Prepared by the Ministerial Legal Task Team 1995 ILJ 278

Memorandum of Objects: Labour Relations Amendment Bill, 2012

\section{List of Abbreviations}

CCMA

CLL

ELJ

IC

ILJ

LAC

LC

LRA of 1956

LRA of 1995

LRAA of 2014

SCA
Commission for Conciliation Mediation and Arbitration

Contemporary Labour Law

Employment Law Journal

Industrial Court

Industrial Law Journal

Labour Appeal Court

Labour Court

Labour Relations Act 28 of 1956

Labour Relations Act 66 of 1995

Labour Relations Amendment Act 6 of 2014

Supreme Court of Appeal 